\title{
Profil Kemampuan Literasi Matematis Siswa Berkemampuan Matematika Tinggi Dalam Menyelesaikan Soal Cerita Berbasis PISA
}

\author{
Evik Kumala Sari ${ }^{1}$, Sugiyanti ${ }^{2}$, Agnita Siska Pramasdyahsari ${ }^{3}$ \\ 1,2,3 Universitas PGRI Semarang, Semarang, Jawa Tengah 50232, Indonesia \\ Pengiriman: 10/Maret/2021; Diterima: 25/Maret/2021; Publikasi: 31/Maret/2021 \\ DOI: https://doi.org/10.31629/jg.v6i1.3286
}

\begin{abstract}
Abstrak
Penelitian ini bertujuan untuk memaparkan kemampuan literasi matematis siswa dengan kemampuan matematika tinggi dalam menyelesaikan soal cerita aritmatika sosial. Jenis penelitian ini merupakan penelitian deskriptif kualitatif. Subjek yang diambil adalah satu siswa kelas VII SMP yang memiliki kemampuan matematika tinggi. Data penelitian diambil melalui dokumentasi, tes tertulis kemampuan literasi matematis dan wawancara. Teknik pemeriksaan keabsahan data menggunakan triangulasi teknik yaitu membandingkan hasil tes kemampuan literasi matematis dengan hasil wawancara. Berdasarkan hasil analisis, siswa dengan kemampuan matematika tinggi memenuhi indikator kemampuan literasi matematis PISA yaitu, 1) mampu melaksanakan prosedur dalam memecahkan masalah dengan jelas, termasuk prosedur yang memerlukan keputusan secara berurutan, 2) mampu menyelesaikan masalah dan menggunakan strategi yang sederhana, 3) mampu menggunakan dan menafsirkan representasi dari sumber informasi yang berbeda serta menjelaskan alasannya secara langsung, 4) mampu mengkomunikasikan hasil interpretasi dan alasan mereka.
\end{abstract}

Kata kunci: kemampuan matematika; kemampuan literasi; PISA

\begin{abstract}
This study aims to expose the mathematical literacy skills of students with high math skills in solving social arithmetic story problems. This type of research is qualitative descriptive research. The subject taken was one grade VII junior high school student who had high math skills. The research data was taken through documentaion, written tests of mathematical literacy skills, and interviews. Data validity check technique using triangulation technique is comparing the results of mathematical literacy ability test with interview results. Based on the results of the analysis, shows that students with high math skills meet the indicators of PISA mathematical literacy ability namely, 1) able to carry out procedures in solving problems clearly, including procedures that require successive decisions, 2)able to solve problems and use simple strategies, 3) able to use and interpret representations of different sources of information and explain the reasons directly, 4)able to communicate the results of their interpretations and reasons.
\end{abstract}

Keywords: math skills; literacy skills; PISA

*Penulis Korespondensi

Email Address: evikkumala77@gmail.com

Handphone : +6282335565205 


\section{JURNAL GANTANG. Maret 2021; VI(1): 83 - 92 \\ p-ISSN. 2503-0671 \\ e-ISSN. 2548-5547}

\section{Pendahuluan}

Matematika sebagai salah satu ilmu yang diajarkan, hakikatnya tidak hanya menuntut siswa untuk menjadi manusia kalkulator yang hanya mampu berhitung atau mengaplikasikan rumus dalam memecahkan masalah saja. Namun, juga dapat melatih kemampuan berpikir dan analisisnya dalam menghadapi masalah kehidupan sehari-hari. Menurut Depdiknas (2006), Matematika ada sebagai bentuk pemikiran manusia yang berhubungan dengan prose, ide dan penalaran. Pembelajaran matematika penting diberikan kepada siswa sebagai dasar kemampuan berpikir logis, sistematis, analisis, dan kritis. Sejalan dengan hal ini, Programme for International Student Assessment (PISA) mendefinisikan literasi matematis sebagai berikut, "Mathematical literacy is an individual's capacity to formulate, employ, and interpret mathematics in a variety of contexts. It includes reasoning mathematically and using mathematical concepts, procedures, facts and tools to describe, explain and predict phenomena." (OEDC, 2013). Menurut PISA, literasi matematika adalah kemampuan seseorang untuk mempekerjakan, merumuskan, dan menafsirkan matematika dalam berbagai konteks yang mencakup prosedur, fakta, konsep, dan alat matematis untuk menjelaskan, menggambarkan dan memprediksi fenomena (Anwar, 2018). Secara sederhana, menurut Ojose (2011) literasi matematika adalah pengetahuan dasar matematika yang digunakan untuk kehidupan sehari-hari. Kusumawardani dkk, (2018) menambahkan, seseorang yang memiliki kemampuan literasi matematis akan menyedari dan memahami konsep matematika yang relevan dengan masalah yang dihadapinya.

Akan tetapi, kemampuan literasi matematis siswa Indonesia masih tergolong rendah. Hal ini dapat dilihat dari data yang disajikan pada laman Kementrian Pendidikan dan Kebudayaan yang menyatakan jika hasil Studi Programme for International Student Assessment (PISA) 2018 yang dirilis oleh Organisation for Economic Co-operation and Development
(OECD) (Kebudayaan, 2019) menunjukkan bahwa kemampuan literasi siswa Indonesia dalam matematika mencapai 379 dengan skor rata-rata OECD 487. Nilai ini menunjukkan jika kemampuan literasi matematis siswa Indonesia masih di bawah standar. Jika dilihat secara nasional, matematika merupakan mata pelajaran dengan prestasi paling rendah dibandingkan mata pelajaran lain. Hasil ujian nasional tahun 2018/2019 seperti yang dimuat pada laman Pusat Penilaian Pendidikan Kementrian Pendidikan dan Kebudayaan (2019) menunjukkan jika nilai rerata mata pelajaran matematika menjadi nilai yang paling rendah yaitu 46,8 dengan nilai ujian paling tinggi pada Bahasa Indonesia yaitu 66,16.

Sejalan dengan hal ini, pada penelitian yang dilakukan oleh Puspitasari dkk (2015) siswa berkemampuan matematika rendah dan siswa berkemampuan matematika sedang berada pada level 2 kemampuan literasi matematis, sedangkan siswa berkemampuan matematika tinggi berada pada level 3 kemampuan literasi matematis. Sedangkan menurut Khoirudin dkk, (2017) siswa dengan kemampuan literasi matematika rendah, berada pada level 1 literasi matematis PISA. Hal ini menunjukkan jika salah satu faktor rendahnya kemampuan literasi matematis adalah dikarenakan oleh rendahnya kemampuan matematika siswa.

Secara teori, menurut Solaikah (2013) kemampuan matematika adalah kemampuan untuk menyusun, menggali, dan membuat alasanalasan yang logis untuk menyelesaikan masalah matematika dan untuk menghubungkan berbagai ide dalam matematika serta untuk mengkomunikasikan, mengemasi dan melalui matematika. Sedangkan Putri \& Manoy (2013) mengungkapkan, kemampuan matematika adalah kesanggupan atau kecakapan yang dimiliki dimiliki siswa dalam pelajaran matematika. Sehingga dapat didefinisikan bahwa kemampuan matematika adalah kemampuan, kesanggupan, atau kecakapan yang dimiliki siswa dalam menyelesaikan permasalahan matematika.

Menurut Ahyan dkk, (2014) literasi mmatematis dapat ditinjau dari tiga komponen 
yaitu konteks, konten, dan proses matematika Oleh karena itu, dimungkinkan salah satu cara untuk mengukur kemampuan litersi matematika siswa adalah dengan melalui tes uraian yang berupa soal cerita. Hal ini sejalan dengan pendapat Supardi, (2015) yang mengatakan bahwa bentuk tes uraian memberi kesempatan kepada siswa untuk menganalisis, menyusun, dan mensintesiskan ide-ide sehingga siswa harus mengembangkan sendiri hasilnya serta menuliskannya dalam bentuk yang terorganisasi atau tersusun. Sedangkan soal cerita matematika adalah modifikasi soal matematika yang berkaitan dengan kehidupan sehari-hari (Kurniayu, 2012). Laily, (2014) menambahkan bahawa soal cerita berupa kalimat verbal sehari-hari yang dapat dinyatakan dalam simbol matematika. Sejalan dengan hal ini, Newman (Oktaviana, 2017) mengatakan jika dalam menyelesaikan soal cerita matematika, maka siswa harus melalui lima langkah, yaitu: (1) membaca soal (reading), (2) memahami masalah (comprehension), (3) transformasi (transformation), (4) keterampilan proses (process skill), dan (5) penulisan jawaban akhir (encoding).

Salah satu soal cerita yang sering ditemui dalam pembelajaran di sekolah adalah soal cerita materi Aritmatika Sosial. Aritmatika sosial merupakan salah satu materi yang dipelajari dalam matematika. Cakupan materi aritmatika sosial yang diajarkan pada satuan pendidikan SMP/MTs meliputi keuntungan dan kerugian, bunga tunggal, Bruto, neto, dan tara (As'ari dkk, 2017). Berdasarkan hasil wawancara dengan guru mata pelajaran matematika SMP N 1 Sumber, sebagian besar siswa masih kesulitan dalam menyelesaikan soal matematika yang berupa soal uraian. Sedangkan dalam materi aritmatika sosial, sebagian besar soal berupa soal cerita. Kesulian siswa dalam menyelesaikan soal cerita aritmatika sosial ini, dimungkinkan karena kurangnya kemampuan literasi matematis siswa.

Hasil penelitian terdahulu yang dilakukan oleh Khoirudin dkk, (2017) menunjukkan jika siswa berkemampuan matematika rendah berada pada level 1 kemampuan literasi matematis.
Terdapat beberapa perbedaan dalam penelitian ini, yaitu subjek yang digunakan oleh Khoirudin dkk, (2017) adalah kelas VIII SMP, sedangkan pada penelitian ini menggunakan subjek kelas VII SMP. Hal ini bertujuan untuk mengetahui lebih dini kemampuan literasi matematis siswa sehingga guru dapat meningkatkan sistem pembelajarannya agar siswa dapat mencapai kemampuan literasi matematis yang lebih baik. Selain itu, peninjauan yang digunakan oleh Khoirudin dkk, (2017) adalah siswa berkemampuan matematika rendah, sedangkan pada penelitian ini digunakan peninjauan dari siswa berkemampuan matematika tinggi.

Berpijak dari apa yang telah disebutkan di atas dan mengingat pentingnya literasi matematika dalam menyelesaiakan masalah matematika, peneliti merasa perlu untuk mengetahui bagaimana profil kemampuan literasi matematis siswa, salah satunya dalam menyelesaikan soal cerita materi aritmatika sosial berbasis PISA, jika ditinjau dari kemampuan matematika siswa. Harapannya, dengan penelitian ini, dapat diperoleh data yang akurat sehingga dapat mendeskripsikan dengan tepat kemampuan literasi matematis siswa dengan kemampuan matematika tinggi. Hal ini bertujuan agar dapat memperkirakan seberapa maksimal kemampuan literasi matematis siswa dalam menyelesaikan permasalahan matematika. Sehingga dapat digunakan sebagai bahan evaluasi guru dalam meningkatkan metode maupun strategi pembelajaran agar kemampuan literasi matematis siswa menjadi lebih baik. Akhirnya, pada penelitian ini dibahas profil kemampuan literasi matematis siswa berkemampuan matematika tinggi dalam menyelesaikan soal cerita aritmatika sosial yang berbasis PISA.

\section{Metode Penelitian \\ Jenis Penelitian}

Jenis penelitian ini merupakan penelitian deskriptif kualitatif. Subjek penelitian adalah satu siswa kelas VII SMP semester genap tahun pelajaran 2020/2021 yang memiliki kemampuan matematika tinggi. Pemilihan subjek berdasarkan 
JURNAL GANTANG. Maret 2021; VI(1): 83 - 92

p-ISSN. 2503-0671

e-ISSN. 2548-5547

pada nilai ujian akhir siswa yang kemudian dikelompokkan berdasarkan kategori rendah, sedang, dan tinggi menurut (Maksum, 2014) yaitu sebagai berikut:

1. Siswa berkemampuan matematika rendah yang memiliki nilai $\leq 40$;

2. Siswa berkemampuan matematika sedang yang memiliki nilai $41<$ nilai $<70$

3. Siswa berkemampuan matematika tinggi yang memiliki nilai $\geq 71$

\section{Metode Pengumpulan Data}

Teknik pengumpulan data yang digunakan pada penelitian ini andalah teknik tes, wawancara, dan dokumentasi.

\section{Tes Tertulis}

Pada penelitian ini digunakan tes tertulis berupa soal uraian yang terdiri dari enam soal cerita materi aritmatika sosial dengan menggunakan indikator level PISA.

2. Tes Wawancara

Tes wawancara pada penelitian ini, berisi butiran-butiran pertanyaan yang dibuat guna membantu mengklarifikasi jawaban siswa pada tes sebelumnya. Pertanyaan dalam soal dikaitkan dengan indikator kemampuan literasi PISA.

3. Dokumentasi

Dokumentasi dalam penelitian ini dilakukan dengan mengumpulkan nilai akhir semester gasal siswa untuk menentukan subjek penelitian.

\section{Metode Analisis Data}

Analisis data pada penelitian ini mengacu pada (Sugiyono, 2014) yaitu mengadakan reduksi data tes dan wawancara, penyajian data tes dan wawancara, dan penarikan kesimpulan. Hasil tes kemudian dianalisis berdasarkan indikator kemampuan literasi matematis PISA yang dikemukakan oleh Johar, (2012)

\section{Hasil dan Pembahasan}

Berdasarkan pengelompokan siswa dengan kemampuan matematika, diperoleh siswa berkemampuan matematika rendah sebanyak 9 siswa, siswa berkemampuan matematika sedang sebanyak 17 siswa dan siswa berkemampuan matematika tinggi sebanyak 6 siswa. Selanjutnya, dipilih satu siswa dengan nilai tertinggi dikategori tinggi. Teknik pemilihan ini, dilakukan agar mendapat data yang lebih akurat mengenai kemampuan literasi matematis jika ditinjau dari siswa berkemampuan matematika tinggi.

Pada penelitian ini, digunakan indikator kemampuan literasi matematis level PISA menurut Johar (2012). Terdapat enam level atau tingkat kemampuan literasi matematis PISA. Berikut keenam level dan indikatornya yang disajikan pada Tabel 1 .

\section{Kemampuan Literasi Matematis Level 1}

Untuk mengukur kemampuan literasi matematis siswa pada level 1, diberikan soal nomor 1a. Berikut jawaban siswa berkemampuan matematika tinggi (LCDP)

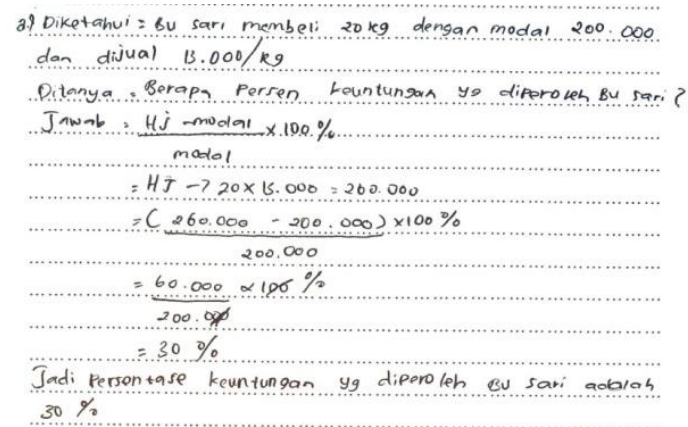

Gambar 1 Jawaban LCDP pada nomor 1a

Berdasarkan hasil jawaban subjek LCDP pada soal nomor 1a, subjek mampu menjawab pertanyaan dengan konteks yang dikenal yaitu mampu menuliskan apa yang diketahui dan ditanyakan pada soal. Hal ini, juga dapat dilihat pada kutipan wawancara berikut:

P : Coba kamu jelaskan permasalahan apa yang ada pada soal tersebut?

LCDP : Disuruh mencari persentase keuntungan yang didapat Ibu Sari

P : Okey, sekarang coba kamu sebutkan informasi apa yang kamu ketahui dari soal tersebut?

LCDP : Yang diketahui itu, Bu sari membeli $20 \mathrm{~kg}$ jeruk. Modalnya Rp200.000,00, terus harga satu kg jeruk Rp13.000,00. 
Tabel 1

Indikator kemampuan literasi matematis PISA

\begin{tabular}{|c|c|}
\hline Level & Kompetensi Matematika \\
\hline 1 & $\begin{array}{l}\text { a. Mampu menjawab pertanyaan dengan konteks yang dikenal dengan informasi yang relevan. } \\
\text { b. Mampu mengidentifikasi informasi dan menggunakan cara-cara yang umum berdasarkan } \\
\text { intruksi yang jelas } \\
\text { c. Mampu menunjukkan suatu tindakan sesuai dengan stimulasi yang diberikan }\end{array}$ \\
\hline 2 & $\begin{array}{l}\text { a. Mampu mengenali dan menafsirkan situasi dengan konteks yang membutuhkan kesimpulan } \\
\text { langsung } \\
\text { b. Mampu memilih informasi yang relevan dan menggunakan cara penyajian tunggal } \\
\text { c. Mampu mengerjakan algoritma dasar dan menggunakan rumus } \\
\text { d. Mampu memberi alasan dari hasil peyelesaian secara tepat. }\end{array}$ \\
\hline 3 & $\begin{array}{l}\text { a. Mampu melaksanakan prosedur dengan jelas, termasuk prosedur yang memerlukan } \\
\text { keputusan secara berurutan. } \\
\text { b. Mampu menyelesaikan masalah dan menggunakan strategi yang sederhana. } \\
\text { c. Mampu menggunakan dan menafsirkan representasi dari sumber informasi yang berbeda } \\
\text { d. Mampu mengkomunikasikan alasan dan hasil interpretasinya. }\end{array}$ \\
\hline 4 & $\begin{array}{l}\text { a. Mampu menggunakan model secara efektif dalam situasi yang konkret tetapi kompleks } \\
\text { b. Mampu menggabungkan dan memilih representasi yang berbeda serta menghubungkannya } \\
\text { dengan situasi nyata. } \\
\text { c. Mampu menggunakan berbagai keterampilannya dan menunjukkan alasan dengan beberapa } \\
\text { d. Mampangan dengan jelas. } \\
\text { d. Mampu mengomunikasikan dan menjelaskan hasil interpretasi dan tindakan mereka. }\end{array}$ \\
\hline 5 & $\begin{array}{l}\text { a. Mampu mengembangkan dan menggunakan model untuk situasi kompleks, menetapkan } \\
\text { asumsi dan mengidentifikasi masalah } \\
\text { b. Mampu memilih, membandingkan, dan mengevaluasi strategi pemecahan masalah dengan } \\
\text { tepat terkait permasalahan kompleks yang berhubungan dengan model. } \\
\text { c. Mampu menggunakan strategis dengan pemikiran dan penalaran yang luas, serta } \\
\text { menghubungkan representasi simbol dan karakteristik formal dan pengetahuan yang } \\
\text { berhubungan dengan situasi } \\
\text { d. Mampu melakukan refleksi dari pekerjaan dan merumuskan serta mengkomunikasikan } \\
\text { penafsiran beserta alasannya }\end{array}$ \\
\hline 6 & $\begin{array}{l}\text { a. Mampu melakukan generalisasi, pengonsepan dan menggunakan informasi berdasarkan } \\
\text { penelaahan dan pemodelan dalam situasi kompleks } \\
\text { b. Mampu menghubungkan sumber informasi berbeda dengan fleksibel dan } \\
\text { menginterpretasikannya } \\
\text { c. Mampu menerapkan pemahamannya secara mendalam dengan operasi matematika, } \\
\text { mengembangkan pedekatan dan strategi baru untuk menghadapi situasi baru } \\
\text { d. Mampu mengkomunikasikan dan merumuskan tindakannya dengan tepat dan melakukan } \\
\text { penafsiran dari argumentasinya. }\end{array}$ \\
\hline
\end{tabular}

Berdasarsarkan transkip wawancara, subjek mampu menjelaskan informasi yang didapat dengan menyebutkan apa yang diketahui dan ditanyakan dari soal. Subjek juga mampu mengidentifikasi dan melakukan cara-cara umum berdasarkan instruksi, serta menunjukkan suatu tindakan sesuai stimulasi yang diberikan. Hal ini dapat dilihat dari hasil jawaban LCDP, dimana ia mampu menuliskan apa yang diketahui dan ditanyakan pada soal nomor 1a. Dalam menjawab soal, subjek LCDP mencari harga jual dari seluruh jeruk yang terjual terlebih dahulu, setelahnya ia mengurangi dengan modal. Setelah mendapat hasilnya yaitu Rp 60.000,00 subjek membagi hasilnya dengan modal kemudian mengalikannya dengan 100\%, sehingga mendapat hasil $30 \%$. Jawaban subjek, juga sesuai dengan kutipan wawancara berikut:

P : Coba kamu jelaskan model matematika 
JURNAL GANTANG. Maret 2021; VI(1): 83 - 92

p-ISSN. 2503-0671

e-ISSN. 2548-5547

yang kamu buat tersebut!

LCDP : Pertama dicari dulu harga jualnya, yaitu $\mathrm{HJ}=20 \times 13.000$ hasilnya 260.000, kemudian dikurangi dengan modal yaitu 200.000, lalu dibagi dengan modal lagi dan dikali $100 \%$. Hasilnya jadi $30 \%$

\section{Kemampuan Literasi Matematis Level 2}

Untuk mengukur kemampuan literasi matematis siswa pada level 2, diberikan soal nomor $1 \mathrm{~b}$. berikut jawaban dalam menjawab soal $1 b$.

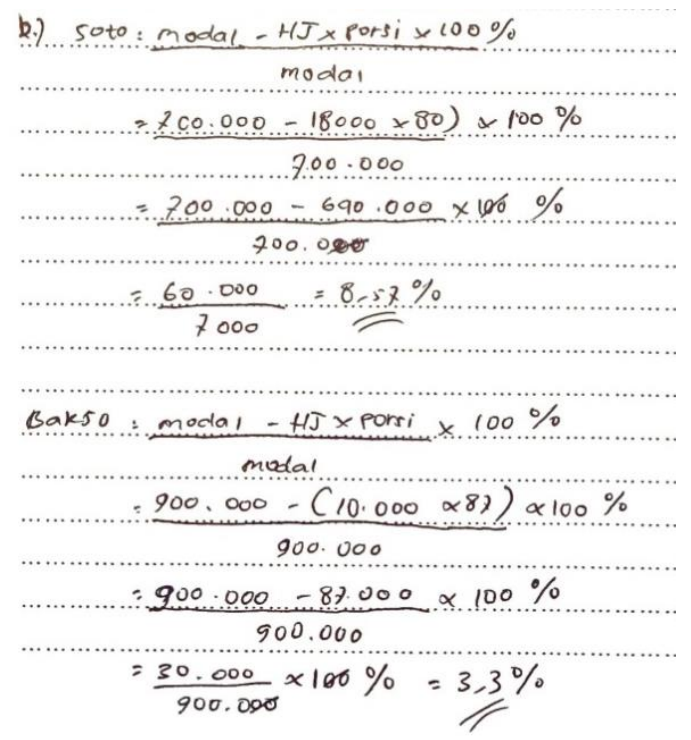

Gambar 2 Jawaban LCDP pada soal 1b

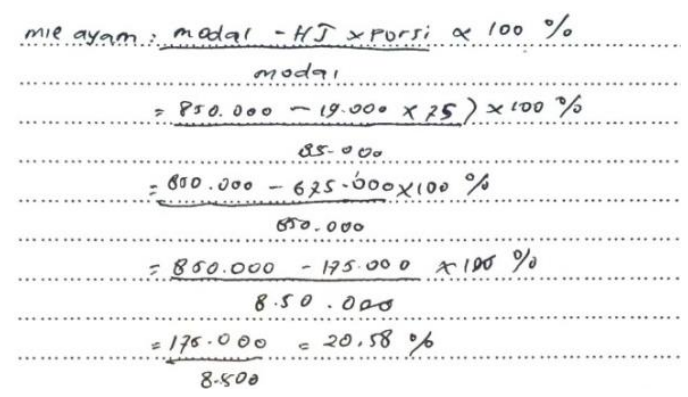

Gambar 3 Lanjutan jawaban LCDP soal 1b

Berdasarkan jawaban subjek LCDP, subjek mampu menafsirkan situasi dari permasalahan yaitu mampu menyebutkan modal, harga jual, dan banyak porsi terjual dari masingmasing jenis makanan yang disajikan pada tabel. Subjek mampu memilih informasi yang relevan dan menggunakan penyajian data tunggal, serta mampu mengerjakan algoritma dasar. Hal ini terlihat pada jawaban subjek dalam menyelesaikan permasalahan pada soal, dimana subjek LCDP menggunakan rumus persentase kerugian. Setelah mendapat hasil dari persentase kerugian dari masing-masing jenis makanan, ia memilih makanan dengan persentase paling tinggi sebagai makanan yang harus duikurangi porsinya agar kerugian lebih sedikit. Subjek LCDP mampu menjawab soal $1 \mathrm{~b}$ dengan benar. Hal ini, sesuai dengan kutipan wawancara LCDP berikut:

P : Coba kamu jelaskan kembali hasil yang kamu dapat

LCDP : Untuk soto, dicari dulu harga jualnya $=$ $8.000 \times 80=640.000$, terus modal 700.000-640.000 $=60.000$. Setelah itu, $\frac{60.000}{700.000} \times 100 \%$, hasilnya $8,57 \%$. Untuk bakso, harga jual $=10.000 \times 87=870.000$ terus modal $900.000-870.000=30.000$ setelah itu $\frac{30.000}{900.000} \times 100 \%$, hasilnya $3,3 \%$. Kalau yang mie ayam harga jual $=9.000 \times 75=675.000$, terus modal 850.000-675.000 $=175.000$. kemudian $\frac{175.000}{850.000} \times 100 \%$, hasilnya 20,58\%. Jadi, Pak Cahyo harus mengurangi prosi mie ayam.

\section{Kemampuan Literasi Matematis Level 3}

Untuk mengukur kemampuan literasi matematis siswa pada level 3, diberikan soal nomor 2a. Berikut jawaban dalam menjawab soal 2a.

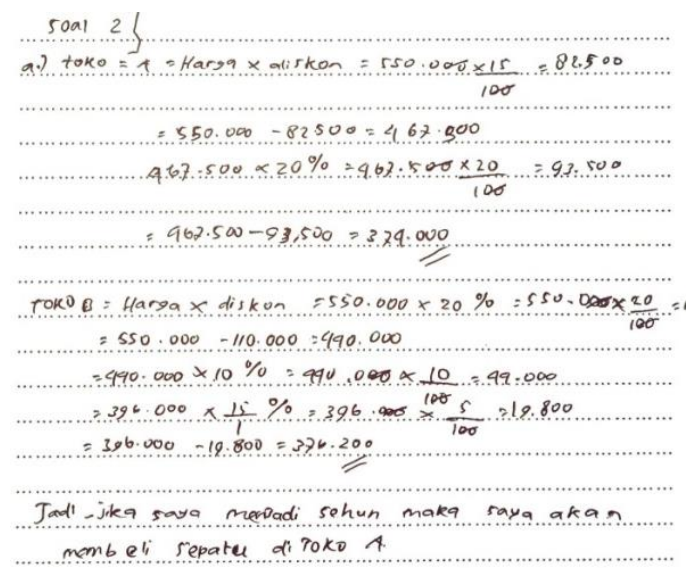

Gambar 4 Jawaban LCDP pada soal 3a 
Berdasarkan jawaban subjek LCDP, subjek mampu melaksanakan prosedur dengan jelas. Hal ini terlihat pada jawaban subjek dimana subjek LCDP mencari diskon dari masing-masing toko. Ia mencari setiap harga setelah diskon, dari persentase yang diberikan. Subjek mampu memecahkan masalah dan menetapkan strategi yang sederhana, dan mampu menafsirkan dan menggunakan representasi berdasarkan sumber informasi yang berbeda. Dapat dilihat dari jawaban subjek, Pada toko A, subjek LCDP mencari harga setelah diskon $20 \%$ dari Rp550.000 terlebih dahulu sehingga mendapatkan hasil Rp82.500, dari hasil tersebut, ia mengurangkan Rp550.000 - Rp82.000= Rp467.500. Setelahnya subjek mencari harga diskon 15\% dari Rp467.500 dan mendapat hasil Rp93.500. Kemudian subjek menjari harga yang harus dibayar Sehun dengan mengurangkan Rp467.500 - Rp93.500 = Rp 374.000. Subjek LCDP melakukan cara yang sama untuk mencari harga sepatu di toko $\mathrm{B}$, sehingga subjek mendapat jawaban bahwa toko A lebih murah dari toko B. Subjek juga dapat mengkomunikasikan hasil interpretasinya, Hal ini, sesuai dengan kutipan wawancara berikut:

P :Setelah memahami permasalahan dari soal tersebut, cara apa yang kamu gunakan?

LCDP : Mencari harga setelah diskon

$\mathrm{P} \quad$ : Bagaimana caranya?

LCDP : Dicari dulu satu persatu, harga diskon $15 \%$ berapa, kemudian dicari harga setelah diskon. Setelah itu dicari lagi harga diskon $20 \%$ terus baru ketemu jawabannya.

P : Kenapa kamu memakai cara tersebut? Kenapa gak langsung kamu tambahkan, harga diskon $15 \%+20 \%$ ?

LCDP : Kalau langsung nanti diskonnya jadi sama mbak. Jadi saya cari satu-satu.

$P \quad$ :Coba kamu jelaskan kembali jawabanmu

LCDP : Untuk toko A, dicari dulu diskon dari $15 \%$, yaitu $550.000 \times 15 \%=82.500$. kemudian $550.000-82.500=467.500$. terus dicari diskon 20\%. Jadinya, $467.500 \times 20 \%=93.500$, setelah itu dicari harga setelah diskon 467.500$93.500=374.000$. Kalau yang toko B, dicari diskon dari $20 \%$ yaitu 550.0000 $\times 20 \%=110.000$, terus $550.000-110.000$ $=440.000$, setelah itu dicari diskon $10 \%, 440.000 \times 10 \%=44.000$, lalu $440.000-44.000=396.000$, terus dicari lagi $396.000 \times 5 \%=19.800$, habis itu dicari harga 396.000-19.800 $=376.200$. Jadi, jika saya menjadi Sehun, maka saya memilih sepatu di toko A, karena harganya leih murah.

Pada soal yang mengukur kemampuan literasi matematis level 4, level 5, dan level 6 , subjek belum mengerjakan satu pun dari soal yang mengukur level tersebut. Berikut kutipan wawancara subjek LCDP:

$\mathrm{P} \quad$ : Nah kalau untuk soal nomor $2 \mathrm{~b}$ bagaimana? Apakah kamu memahami permasalahannya?

LCDP : Agak bingung Mbak.

$\mathrm{P} \quad$ : Bingungnya kenapa? Di bagian apa?

LCDP : Dibagian grafiknya, saya tidak paham dengan grafiknya.

P : Tapi kamu paham apa yang ditanyakan dari soal itu?

LCDP : paham Mbak

$\mathrm{P} \quad$ : Kalau paham, coba jelaskan apa yang ditanyakan dari soal tersebut?

LCDP : Diminta untuk mencari besar uang Chandra setelah 1,5 tahun.

P : Apa kamu tidak memiliki ide untuk menyelesaikannya?

LCDP : Bingung Mbak.

$\mathrm{P} \quad$ : Okey, untuk nomor 3 bagaimana?

LCDP : Nomor 3 juga bingung Mbak.

$\mathrm{P} \quad$ : Apa yang kamu bingungi?

LCDP : Cara mengerjakannya

$\mathrm{P} \quad$ : Mengapakamu bingung?

LCDP : Karena belum pernah menemui soal yang seperti itu mbak.

P : Apakah kamu belum mempelajari materi bruto, netto, dan tara? 


\section{JURNAL GANTANG. Maret 2021; VI(1): 83 - 92 \\ p-ISSN. 2503-0671 \\ e-ISSN. 2548-5547}

LCDP : Sudah Mbak, tapi biasanya soalnya gak sesusah itu.

Berdasarkan kutipan wawancara tersebut, pada soal $2 \mathrm{~b}$ yang mengukur kemampuan literasi matematis level 4, subjek sebernarnya mampu mengetahui informasi-informasi pada soal, namun subjek mengaku kesulitan untuk menyelesaikannya. Sedangkan pada soal level 5 dan level 6, subjek mengaku belum pernah menemui soal semacam itu.

Dari hasil analisis jawaban di atas, siswa berekmampuan matematika tinggi (LCDP), mampu mengerjakan 3 soal. Siswa mampu menjawab soal 1a yang mengukur kemampuan literasi matematis level 1 dengan tepat. Berdasarkan jawaban subjek pada Gambar 1, siswa mampu menjawab pertanyaan dengan konteks yang dikenal serta informasi yang relevan. Siswa mampu menyelesaikan permasalahan pada soal dengan cara-cara umum. Dan mampu menunjukkan tindakan sesuai dengan stimulasi yang diberikan. Hal ini sesuai dengan indikator kemampuan literasi matematis level 1 yang dikemukakan oleh Johar (2012).

Siswa juga mampu menjawab soal $1 \mathrm{~b}$ yang mengukur kemampuan literasi matematis level 2 dengan tepat. Berdasarkan hasil tes dan wawancara menunjukkan dengan subjek menunjukkan bahwa siswa mampu mengenali dan menafsirkan situasi dari permasalahan pada soal. Siswa juga mampu memilih informasi yang relevan dan mampu mengerjakan algoritma dasar serta mampu menjelaskan alasan yang tepat dari hasil penyelesaiannya. Hal ini nampak dari jawaban siswa pada Gambar 2 dan Gambar 3 serta hasil wawancara. Sejalan dengan indikator level 2 kemampuan literasi matematis PISA (Johar, 2012) siswa mampu memenuhi setiap indikator level 2.

Pada soal 2a yang mengukur kemampuan literasi matematis level 3, siswa mampu menjawab soal dengan benar. Berdasarkan Gambar 4 dan hasil wawancara, siswa mampu melakukan prosedur untuk menyelesaikan soal dengan jelas, termasuk prosedur yang membutuhkan keputusan secara berurutan. Siswa mampu menggunakan strategi yang sederhana untuk memecahkan permasalahan dengan tepat, mampu menggunakan dan menafsirkan representasi dari sumber informasi yang berbeda, dan dapat menjelaskan hasil intepretasinya dengan baik. Menurut Johar (2012) siswa yang memenuhi setiap indikator level 3, dapat dikatakan siswa berada pada kemampuan literasi matematis level 3 .

Pada soal 2b, 3a, dan 3b siswa belum menjawab ketiga soal tersebut. Berdasarkan hasil wawancara, siswa mengaku bingung dalam mencari penyelesaian dari permasalahan yang disajikan. Sehingga dapat dikatakan siswa belum memenuhi setiap indikator pada level 4 , level 5, dan level 6.

Berdasarkan analisis hasil tes tetulis dan wawancara, siswa hanya memenuhi 3 dari 6 level kemampuan literasi matematis PISA, sehingga dapat dikatakan siswa berada pada level 3 kemampuan literasi matematis. Hal ini sejalan dengan pendapat Puspitasari, dkk (2015) bahwa siswa dengan kemampuan matematika tinggi berada pada level 3 kemampuan literasi matematis.

\section{Kesimpulan}

Berdasarkan penelitian yang telah dilakukan, dapat disimpulkan bahwa siswa dengan kemampuan matematika tinggi memenuhi indikator dari 3 level kemampuan literasi matematis yaitu:

a. Pada level 1, siswa mampu menjawab pertanyaan dengan konteks yang dikenal, mampu mengidentifikasi informasi dan melakukan cara-cara yang umum, serta mampu melakukan suatu tindakan dengan stimulasi yang diberikan.

b. Pada level 2, siswa mampu menafsirkan situasi dengan konteks yang dikenal, mampu memilih informasi yang relevan dan menggunakan cara penyajian tunggal, mampu mengerjakan algoritma dasar, dan mampu memberi alasan secara tepat dari hasil penyelesaian.

c. Pada level 3, yaitu siswa mampu melakukan prosedur dengan jelas dalam memecahkan 
masalah dan menggunakan strategi yang sederhana, mampu menggunakan dan menafsirkan representasi berdasarkan informasi yang berbeda, serta mampu menjelaskan alasan dan hasil interpretasinya.

\section{Referensi}

Ahyan, S., Zulkardi, \& Darmawijoyo. (2014). Developing mathematics problems based on pisa level of change and relationships content. IndoMS-JME, 47-56.

Anwar, N. T. (2018). Peran kemampuan literasi matematis pada pembelajaran matematika abad-21. Prisma, Prosididing Seminar Nasional Matematika, 364-370.

As'ari, A. R., Tohir, M., Valentino, E., \& Taufiq, I. (2017). Matematika. Jakarta: Pusat Kurikulum dan Perbukuan, Balitbang, Kemendikbud.

Depdiknas. (2006). Kurikulum tingkat satuan pendidikan. Jakarta: Depdiknas.

Johar, R. (2012). Domain Soal PISA untuk Literasi Matematika. Jurnal Peluang, 3041.

Kementerian Pendidikan dan Kebudayaan. (2019). Hasil PISA Indonesia 2018. Diambil pada desember 2020 dari https://www.kemendikbud.go.id/main/bl og/2019/12/hasil-pisa-indonesia-2018akses-makin-meluas-saatnya-tingkatkankualitas

Kementerian Pendidikan dan Kebudayaan. (2019). Laporan hasil ujian nasional. Diambil pada 5 Desember 2020 dari https://puspendik.kemdikbud.go.id/hasilun/

Khoirudin, A., Setyawati, R. D., \& Nursyahida, F. (2017). Profil kemampuan literasi matematika siswa berkemampuan matematis rendah dalam menyelesaikan soal berbentuk PISA. Aksioma, 33-42.

Kurniayu, F. A. (2012). Kesalahan-kesalahan dalam menyelesaikan soal cerita matematika pada siswa kelas VI sekolah dasar negeri Se-Kecamatan Gebang Kabupaten Purworejo. Doctoral Dissertation Matematika.
Kusumawardani, D. R., Wardono, \& Kartono. (2018). Pentingnya penalaran matematika dalam meningkatkan kemampuan literasi matematika. Prisma, Prosiding Seminar Nasional Matematika, 588-595.

Laily, I. F. (2014). Hubungan kemampuan membaca pemahaman dengan kemampuan memahami soal cerita matematika sekolah dasar. Eduma: Mathematics Education Learning and Teaching.

Maksum, A. (2014). Profil kemampuan penalaran matematis siswa dalam menyelesaikan soal bangun ruang sisi lengkung. STIKIP PGRI Semarang.

OEDC. (2013). PISA 2012 assessment and analitycal framework: Mathematics, reading, science. OECD Publishing.

Ojose, B. (2011). Matematics literacy: Are we able to put the mathematics we learn into everyday use. Jurnal of Mathematics Educations, 89-100.

Oktaviana, D. (2017). Analisis tipe kesalahan berdasarkan teori newman dalam menyelesaikan soal cerita pada mata kuliah matematika diskrit. Edu Sains: Jurnak Pendidikan Sains \& Matematika, 22-31.

Puspitasari, A., Setiawani, S., \& Sri, N. D. (2015). Analisis kemampuan literasi matematis siswa kelas X MIPA 5 SMA Negeri 1 Ambulu berdasarkan kemampuan matematika. Altikel Ilmiah Mahasiswa, 16.

Putri, L. F., \& Madoy, J. T. (2013). Identifikasi kemampuan matematika siswa dalam memecahkan masalah aljabar di kelas VIII berdasarkan taksonomi Solo. MATEdunesa, 2(1), 1-8.

Solaikah, Afifah, D. S., \& Suroto. (2013). Identifikasi kemampuan siswa dalam menyelesaikan soal aritmatika sosial ditinjau dari perbedaan kemampuan matematika. Jurnal Pendidikan Matematika STIKIP PGRI Sidoarjo, 97106.

Sugiyono. (2014). Metode penelitian pendekatan kuantitatif kualitatif dan R\&D. Alfabeta. 
JURNAL GANTANG. Maret 2021; VI(1): 83 - 92

p-ISSN. 2503-0671

e-ISSN. 2548-5547

Supardi. (2015). Hasil belajar matematika siswa ditinjau dari interaksi tes formatis uraian dan kecerdasan emosional. Jurnal Ilmiah Pendidikan MIPA, 78-96. 